\title{
Durability of Hardened Portland Cement Paste used for Oilwell Cementing
}

\author{
E. Lécolier, A. Rivereau, G. Le Saoût*, A. Audibert-Hayet** \\ Institut français du pétrole, IFP, Division Chimie et Physico-Chimie Appliquées, 1-4 avenue de Bois Préau, 92852 Rueil-Malmaison cedex, France \\ e-mail: eric.lecolier@ifp.fr - alain.rivereau@ifp.fr - gwenn.lesaouł@epfl.ch - annie.audibert-hayet@total.com \\ * Present address: Laboratoire de Matériaux de Construction, EPFL, 1015, Lausanne, Suisse \\ ** Present address: TOTAL, place de la Coupole, 92400 La Défense France
}

Résumé - Durabilité d'une pâte de ciment durcie utilisée pour la cimentation des puits pétroliers - Les problèmes de durabilité des matériaux utilisés pour les sondages pétroliers sont une question essentielle pour l'industrie pétrolière. Nous avons mené des essais de vieillissement d'une pâte de ciment dans deux types de fluides en variant la procédure expérimentale. Nous montrons que les altérations observées sont très dépendantes de la façon dont les essais sont menés. Pour évaluer correctement la durabilité à long terme des matériaux cimentaires, il est notamment nécessaire de renouveler périodiquement le fluide dans lequel le matériau vieillit. En menant les essais ainsi, on montre que les propriétés macroscopiques d'une pâte de ciment durcie sont fortement dégradées.

Abstract - Durability of Hardened Portland Cement Paste used for Oilwell Cementing Durability of materials used for the completion of oilwell is of utmost importance for oil and gas industry. We carried out ageing tests on a hardened cement paste in two types of fluid by varying the experimental procedure. We show that the observed alterations are highly dependent on the way of conducting the tests. To correctly assess the long-term durability of cement-based materials, it is necessary to renew periodically the ageing fluid. By doing so, a severe impairment of the macroscopic properties of an hardened cement paste aged in a monthly-replaced brine can be observed. 


\section{INTRODUCTION}

Different materials are found in an oil well: steel for casing string, polymer for packers and cement-based materials for annular sealing. Each of these materials has to keep its integrity not only during the production period but also after the abandonment of the well. During the production period, in order to ensure a high production rate, no undesired circulation of fluids (typically water influx/produced fluids) or casing failure should occur within the well. After the closure of the well, failure of the zonal isolation may lead to severe problems of environment as, for example, leakage of polluting fluids to the surface. Therefore, the zonal isolation must be effective for hundreds or thousands of years. Achieving effective zonal isolation requires to correctly design the architecture of the well, to succeed the primary cementing job and to select and use appropriate materials. Durability of oilwell materials is a very challenging topic, specially for cementitious materials which must prevent any fluid circulation.

Moreover, over the next few decades, the production of oilfields with high contents of associated sour gases is planned to increase. We estimate that $40 \%$ of the world remaining gas reserves contain more than $2 \%$ of $\mathrm{CO}_{2}$ and/or more than $100 \mathrm{ppm}$ of $\mathrm{H}_{2} \mathrm{~S}$. Consequently, the researchs on technologies to produce such fields are of utmost importance. Due to the presence of corrosive gas, special attention has to be paid to the design of well materials (casing, cementing materials). Corrosion of steel induced by acid gas-containing brines is well documented while data on degradation by wet $\mathrm{CO}_{2}$ or wet $\mathrm{H}_{2} \mathrm{~S}$ is more limited [1]. For cementitious materials, there is an abundant literature dealing with deterioration of cement pastes caused by a $\mathrm{CO}_{2}$ environment [2-5]. Published data on degradation mechanisms of cement-based materials exposed to $\mathrm{H}_{2} \mathrm{~S}$ environments are more scarce $[6,7]$.

To correctly assess oilwell cement durability, ageing tests must be carried out with fluids which are representative of the different life periods of the different types of well. For wells drilled in areas with high contents of $\mathrm{H}_{2} \mathrm{~S}$ or mixed $\mathrm{H}_{2} \mathrm{~S} / \mathrm{CO}_{2}$, one can consider the following situations as critical from a chemical point of view for the cement sheath:

- primary cementing across the cap rock and the reservoir during the production,

- primary cementing during acid gas injection (in case of fluid re-injection),

- primary cementing and plugs after the end of the production and re-injection operations.

For each of the above mentioned situations, the environment of the cement sheath changes: nature (supercritical fluid, gas, liquid) and composition of the fluid in contact with the cement, presence of water, pressure and temperature. So different situations have to be carefully studied in order to assess the durability of the zonal isolation.
This paper deals with the durability of cement-based materials used for oilwell cementing. We focus on the chemical evolution of such materials when in contact with different field fluids and its impact on some macroscopic properties (mechanical resistance, permeability). We present results of ageing of hardened cement paste corresponding to three different experimental conditions. In the first condition, the cementitious material is aged in water without fluid renewal. For the second condition, the cement paste is aged in water which is periodically renewed. And, for the third condition, the cementitious material is aged in crude oil in order to simulate the conditions of the reservoir. We discuss the different results obtained for the three ageing conditions. We draw some conclusions about the best ways to carry out ageing tests in order to assess the long term structural life of cementing materials.

\section{BACKGROUND}

\subsection{Oilwell Cementing [8]}

Rotary drilling is the worldwide method used to drill oil and gas wells. This method consists in the use of a rotating bit which crushes the rock formation, and a continuous drilling fluid injection, which removes the rock cuttings and brings them to the surface. One of the main advantages of the rotary method is that the drilling fluid can be pumped through the bit. Once a section of the well has been drilled, the drill pipe is removed from the hole and a casing pipe is run into the hole until it reaches the bottom. This operation is achieved with the borehole full of drilling fluid. Once the casing pipe is in place, a cement slurry is pumped down into the casing string to the bottom of the well and then flows up through the annulus between the casing and the borehole wall (Fig. 1). This last operation is called primary cementing.

The major goal of the primary cementing is to provide a complete and permanent zonal isolation within the well bore. This means that the cement sheath must prevent any fluid circulation (gas, oil, water...) between different rocks layers. To achieve this objective, the drilling fluid must be removed from the annulus and the cement slurry put in place. Therefore, good mud removal and cement placement are essential to avoid interzonal fluid flows. Incomplete zonal isolation may lead to environment pollution problems or production rates lower than expected. That is why primary cementing is often considered as one of the most important operations performed in a well. Primary cementing also aims at mechanically securing the casing string to the borehole walls and at protecting the casing from corrosion by the fluids contained in the drilled rock formations. 


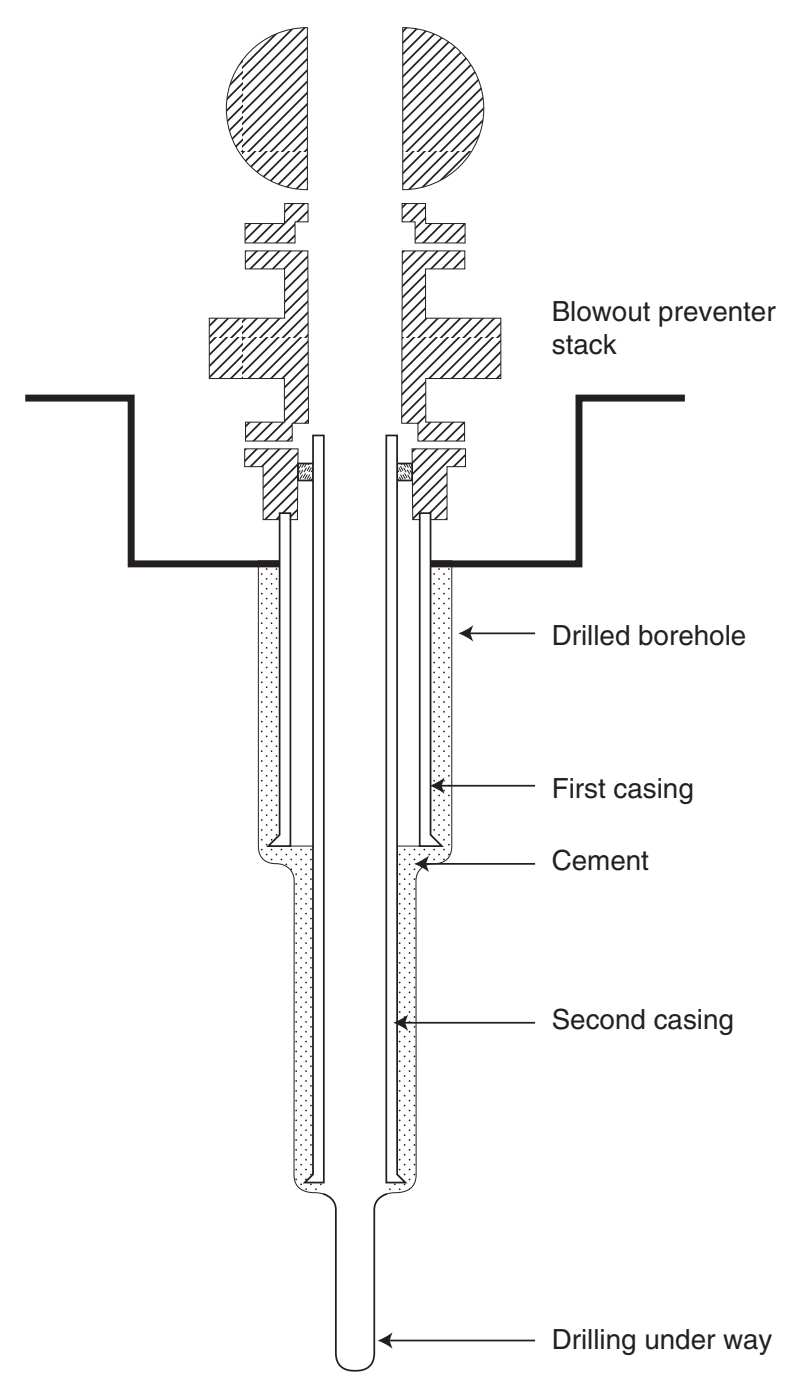

Figure 1

Simplified cross-section of a borehole.

Primary cementing is not the only cementing operation. After 25 years or so, when the production rate becomes very low, the wells have to be plugged. The main aim of well abandonment is to permanently seal the well bore for a geological time scale in order to prevent any leakage of formation fluids to surface.

Consequently, long-term durability of the materials used for primary cementing and for plugging is of paramount importance.

\subsection{Cement Hydration [8,9]}

The mineral mixture used in cementing operations is either a pure cement paste or a fine mortar, i.e. a mixture of cement and fine mineral particles like silica fume, with organic admixtures. Cement itself is a mixture of several mineral phases, the most abundant being an impure tricalcium silicate, $3 \mathrm{CaO} . \mathrm{SiO}_{2}$ (alite) and its dicalcium equivalent, $2 \mathrm{CaO} . \mathrm{SiO}_{2}$ (belite). Oil well cements are particularly rich in silicate phases. According to American Petroleum Institute standards, tricalcium aluminate content of a class $\mathrm{G}$ cement must be lower than $3 \%$. When cement is mixed with water, it undergoes a dissolution reaction generating, among others, calcium, silicate and aluminate ions in the interstitial solution. After a few hours, new products called "hydrates" precipitate, the most important being calcium-silicate-hydrate (C-S-H) and calcium hydroxyde (portlandite). This dissolution-diffusion-precipitation process yields a geometrically complex interface between the anhydrous silicate and C-S-H on one hand and between the hydrates and the solution on the other hand. As the hydration reaction proceeds, more and more anhydrous material is converted into hydrates, with an overall decrease of the porosity since the volume of hydrates produced by the thorough reaction of tricalcium silicate with water is more than twice the initial anhydrous volume [10].

Two important mechanical events occur during hydration [11]. The first one is a simple gelation of the slurry, due to the high ionic strength of the aqueous phase [12-14]. It occurs quasi-immediately after mixing the cement with water, at virtually zero hydration. The coagulated network has a poor mechanical strength. The second and more important event is setting, which starts a few hours after coagulation. The period between coagulation and setting is (improperly) called the dormant period. In fact, hydrate particles nucleation is occurring, followed by their growth [15]. A continuous reinforcement process is going on in contact areas, leading, at some point, to mechanical percolation (setting). At this point, the shear modulus is in the GPa range. Further hydration and (poorly understood) long term redistribution of matter and voids [16] leads to further reinforcement, over periods of weeks, months or even years. The final microstructure developed during this process is an important key for the long term integrity of the cementing material. Indeed, both chemical reactions and transport of chemical species (water, gas molecules, ionic species) within the cement paste is driven by the texture and the topology of the porous cementitious matrix. Hardened cement paste is a good example of mesoscopic divided material (MDM) for which an internal surface partitions and fills the space in a very complex way $[17,18]$.

\subsection{Durability of Set Cement Paste}

Jacquemet et al. [1] investigated the durability of cement paste aged in brine with acid gas $\left(66 \%\right.$ molar $\mathrm{H}_{2} \mathrm{~S}+34 \%$ molar $\mathrm{CO}_{2}$ ) at $50 \mathrm{MPa}$ and $200^{\circ} \mathrm{C}$. They conducted experiments in carefully controlled conditions $(\mathrm{pH}, \mathrm{Eh})$ providing reliable results for chemical reactions. They showed that initial tobermorite phase has been converted in a calcium- 
depleted one. The released calcium from C-S-H was combined with carbon aqueous species to form calcite. Pyrite formation is observed due the reaction between $\mathrm{H}_{2} \mathrm{~S}, \mathrm{C}_{4} \mathrm{AF}$ and steel. Nonetheless, the authors did not study the evolution of the microstructure (pore size distribution for instance), nor physical properties (such as gas or water permeability) of their degraded cement pastes. Ageing in sour gas (150 ppm of $\mathrm{H}_{2} \mathrm{~S}$ and $22 \%$ molar of $\mathrm{CO}_{2}$ ) brine has been studied by Krilov et al. [6]. It is generally observed that carbonation occurs on cement surface through a time dependence phenomena and may induce a decrease of compressive strength. Experimental results are difficult to interpret, since several minerals can dissolve or precipitate simultaneously. But a severe depletion of calcium on the outer layer is generally observed. Recently, it was shown that the formation of a calcium carbonate-rich layer may retard the leaching phenomenon but does not stop it $[2,5]$.

When in contact with acidic aqueous solutions, acid attack of cementitious materials takes place. In the course of acid attack (for instance, brine acidified by $\mathrm{H}_{2} \mathrm{~S}$ ), $\mathrm{H}_{3} \mathrm{O}^{+}$ions penetrate within the cementitious matrix and induce dissolution of hydration products. Experimental works have shown that the alteration of the cement-based materials depends on the chemical composition of cement as well as the $\mathrm{pH}$ of the acid solution. The rate of the degradation is strongly linked to acid concentration, the type and amount of hydrated phases involved in the reactions. For example, dissolution of ferrite or aluminate phases and the induced leaching of $\mathrm{Fe}^{3+}$ and $\mathrm{Al}^{3+}$ is slower and occurs at lower $\mathrm{pH}$ values than the depletion of $\mathrm{Ca}^{2+}$ from C-S-H and portlandite. As the $\mathrm{pH}$ decreases, portlandite ( $\mathrm{pH}$ stability equals to 12.6), C-S-H ( $\mathrm{pH}$ stability $\sim 10-11$ ), calcium aluminate and ferrite hydrates are successively dissolved. The ultimate material resulting from this alteration process is a silica gel when $\mathrm{pH}$ is below than approximately 2 . For $\mathrm{pH}$ ranging between 4 and 6-7, depleted-calcium hydrates remain with residual aluminate and ferrite hydrates [19].

\section{EXPERIMENTAL PROGRAM}

Materials. Ageing experiments were performed using a portland cement, an API class G one produced by Dyckerhoff which is considered as a representative oilwell cement. Its chemical analysis and mineralogical composition are given in Tables 1 and 2 respectively.

Preparation of specimens. Deionised water was added to the cement powder to produce a paste of water to cement ratio equal to 0.44 . The pastes were prepared according the API specifications. Material cylinders of $2.5 \mathrm{~cm}$ in diameter and $5.0 \mathrm{~cm}$ in height and bars with a section of $2 \times 2 \mathrm{~cm}$ and a length of $16 \mathrm{~cm}$ were prepared for the experimental program. All the samples were cured in water for one month at $80^{\circ} \mathrm{C}$. The curing pressure was $7 \mathrm{MPa}$. After one month, the sam- ples were removed from the pressurized curing chamber and transferred in ageing cells.

TABLE 1

Chemical analysis of API Class G cement

\begin{tabular}{c|c}
\hline Oxide & wt\% \\
\hline $\mathrm{CaO}$ & 64.70 \\
\hline $\mathrm{SiO}_{2}$ & 22.91 \\
\hline $\mathrm{Al}_{2} \mathrm{O}_{3}$ & 3.89 \\
\hline $\mathrm{Fe}_{2} \mathrm{O}_{3}$ & 4.75 \\
\hline $\mathrm{SO}_{3}$ & 1.80 \\
\hline $\mathrm{MgO}$ & 0.74 \\
\hline $\mathrm{Na}_{2} \mathrm{O}$ & 0.10 \\
\hline $\mathrm{K}_{2} \mathrm{O}$ & 0.64 \\
\hline
\end{tabular}

TABLE 2

Bogue composition of API Class G cement

\begin{tabular}{c|c}
\hline Mineral & wt\% \\
\hline $\mathrm{C}_{3} \mathrm{~S}$ & 51.2 \\
\hline $\mathrm{C}_{2} \mathrm{~S}$ & 27.0 \\
\hline $\mathrm{C}_{3} \mathrm{~A}$ & 2.3 \\
\hline $\mathrm{C}_{4} \mathrm{AF}$ & 14.5 \\
\hline
\end{tabular}

Ageing protocol. All the specimen were aged under temperature, $80^{\circ} \mathrm{C}$, and pressure, $7 \mathrm{MPa}$, in static conditions. In a first cell, samples were soaked in water with no renewal. In a second cell, samples were aged in brine which was monthly renewed. The composition of the brine is given in Table 3 which corresponds to ionic strength of $0.4 \mathrm{~mol} \cdot \mathrm{L}^{-1}$. The renewal of the aqueous solution ensure non-equilibrium conditions between pore solution and the ageing medium and consequently avoid saturation concentration conditions. The main drawback of this method is the pressurization-depressurization cycles experienced by the materials specimens at each renewal. Indeed, both depressurization and cooling might induce damage to the samples. In a third cell, samples were put in crude oil in order to simulate conditions experienced by cement-based material in the reservoir. We did not replace this fluid during the ageing test. In the first and third experiment, we used one ageing cell for each ageing time to avoid pressurization-depressurization cycles at each sampling time.

TABLE 3

Composition of the brine

\begin{tabular}{l|c|c|c|c|c|c|c|c}
\hline Ionic species & $\mathrm{Cl}^{-}$ & $\mathrm{Na}^{+}$ & $\mathrm{K}^{+}$ & $\mathrm{HCO}_{3}^{-}$ & $\mathrm{SO}_{4}^{2-}$ & $\mathrm{Ca}^{2+}$ & $\mathrm{Mg}^{2+}$ & $\mathrm{pH}$ \\
\hline Composition $\left(\mathrm{mmol} \cdot \mathrm{L}^{-1}\right)$ & 376 & 343 & 33.5 & 6.4 & 2.3 & 4.1 & 1.5 & 7.7 \\
\hline
\end{tabular}




\section{RESULTS}

\subsection{Characterization of the Tested Cement-Based Material after Curing}

We first characterized hardened cement paste just after curing in temperature and pressure.

From an application point of view (effective zonal isolation), mechanical strength and transport properties are the most important properties.

Porous properties of cement-based materials can be described by different parameters. Relevant parameters are often porosity (corresponding to the void volume/total volume ratio) and pore size distribution. This latter information is somewhat difficult to capture without any artifact. Mercury intrusion porosimetry (MIP) is routinely used to measure the porosity of cement pastes, mortars and concretes. Although this technique is not suited to assess pore size distribution $[20,21]$, we can estimate that the (connected) porosity measured by MIP is meaningful [20]. To determine pore size distribution, alternative methods have been recently developed and successfully applied to cement-based materials [22-24].

In this work, we used MIP to measure porosity of the different samples. After drying, cement paste pieces were placed in the chamber of an automated porosimeter. Mercury was then introduced in the chamber and the pressure subsequently increased up to $400 \mathrm{MPa}$. For each pressure increment, the corresponding volume of intruded mercury is recorded. To interpret pressure values, we used a non modified form of the Washburn-Laplace equation:

$$
d=\frac{4 \gamma \cos (\theta)}{p}
$$

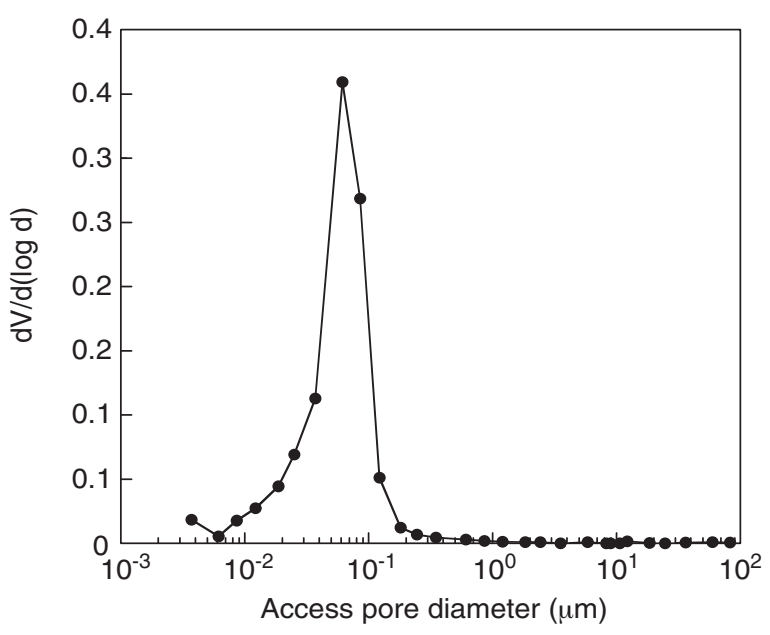

Figure 2

Differential pore size distribution of the hardened cement paste after curing. where $d$ is the pore diameter, $\theta$ is the contact angle between the mercury and the surface of cement matrix, $\gamma$ the surface tension of mercury and $p$ the pressure. The values for $\theta$ and $\gamma$ were assumed to be respectively $141^{\circ}$ and $0.474 \mathrm{~N} \cdot \mathrm{m}^{-1}$.

The connected porosity of the cement paste cured for two weeks is equal to $28 \%$. Even though the pore size distribution measured by MIP is biased, we nonetheless display the differential pore threshold distribution (Fig. 2) as information for comparison (MIP being the only routine technique allowing to determine this property). However, we will not discuss the evolution of this property in the following. Results of an investigation by ${ }^{1} \mathrm{H}$ magnetization relaxation of porous properties of hardened oilwell cement paste have been published elsewhere [25]. In Figure 2, we observe a sharply defined peak for the differential MIP curve indicating a unimodal distribution of access pore sizes. The access pore diameter is about $6 \cdot 10^{-2} \mu \mathrm{m}$.

The mineralogy of the cured paste has been characterized by X-ray diffraction (Fig. 3). X-ray diffraction data were collected using a Philips PW 1820 diffractometer employing the $\mathrm{Cu}_{\mathrm{K \alpha}}$ radiation $\left(\lambda_{0}=0.154 \mathrm{~nm}\right)$. The samples were scanned at $0.6^{\circ}$ per minute between 5 and $65^{\circ} 2 \theta$. Powder XRD analysis indicated that the cement paste comprised anhydrous compounds (alite, belite and brownmillerite), portlandite and katoite. One can also observe a broad peak centered between 2.7 and $3.2 \AA$ corresponding to calcium silicate hydrates, C-S$\mathrm{H}$. Ettringite and AFm were absent. Instead, we detected a siliceous hydrogrossular phase, katoite, corresponding to the solid solution $\mathrm{C}_{3} \mathrm{AS}_{3-\mathrm{x}} \mathrm{H}_{2 \mathrm{x}}$ (where $\mathrm{x}=1.5-3$ ).

Figures 4 and 5 show scanning electron micrographs with two different magnifications of the one-month hydrated cement matrix. On photograph 4, we can note that the matrix is compact. We do not observe large porous areas. We can also

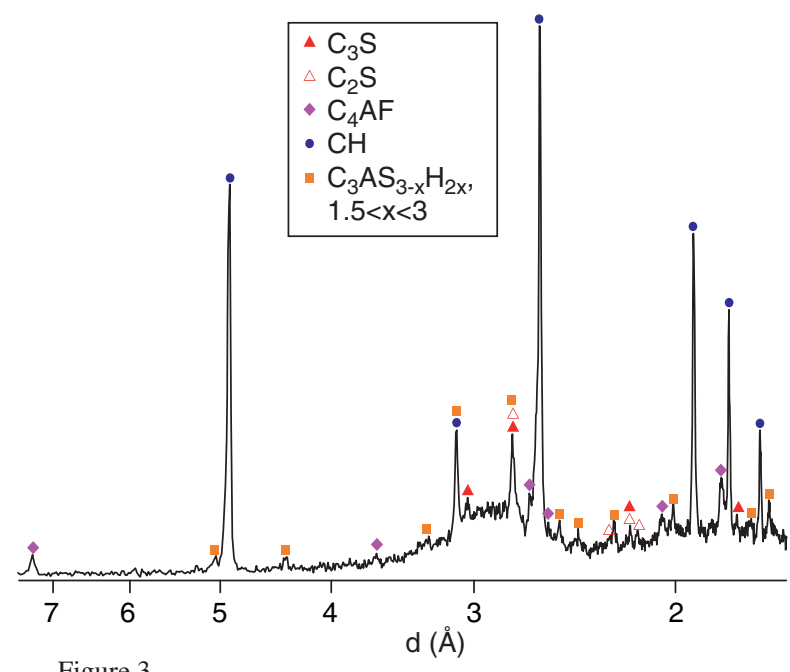

Figure 3

XRD pattern of hardened cement paste after initial curing. 


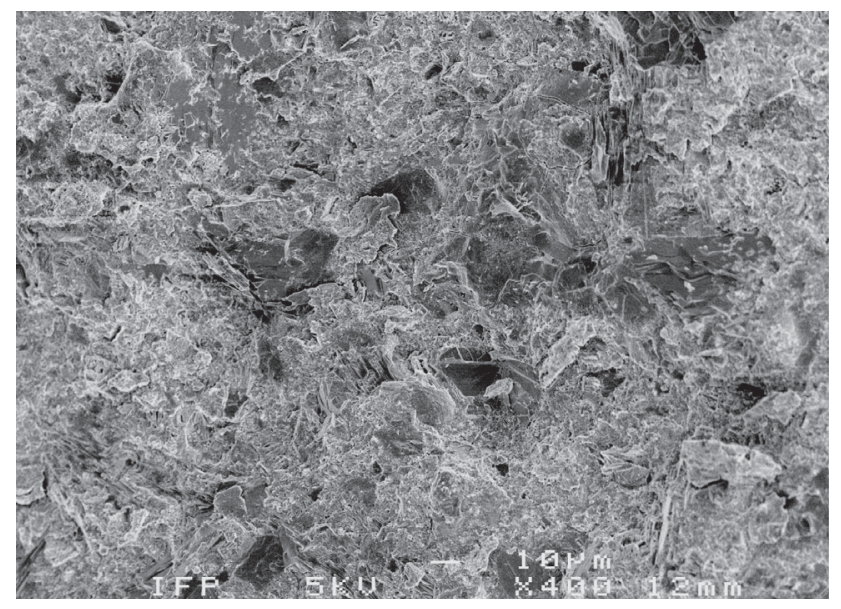

Figure 4

Scanning electron image of fracture of the hardened cement paste after curing.

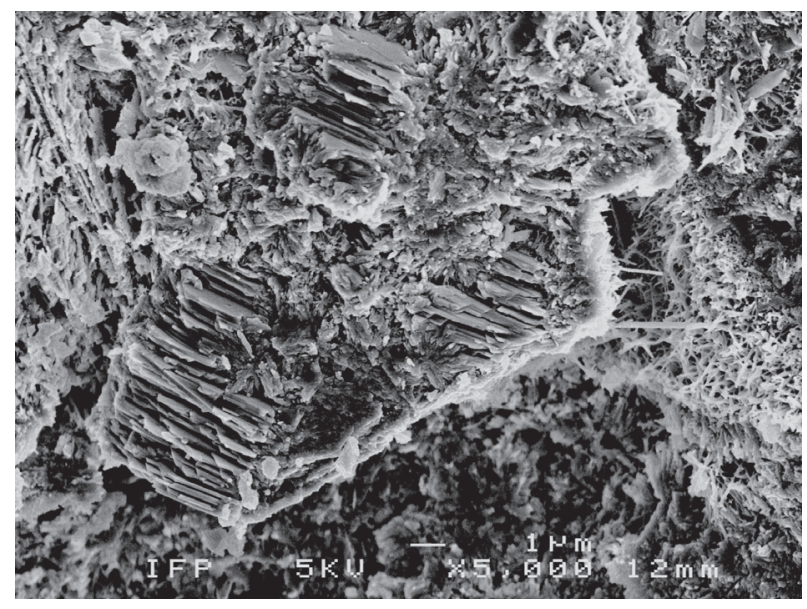

Figure 5

Scanning electron image of fracture of the hardened cement paste after curing. distinguish unhydrated cement grains (in agreement with XRD observations). On photograph 5, one can observe $\mathrm{CH}$ crystals occurring as micrometric platelets. Some calcium silicate hydrates appear as fibrous bodies.

More detailed information on the chemical composition of an oilwell cement paste hydrated at $80^{\circ} \mathrm{C}$ and $7 \mathrm{MPa}$ are given in reference [26].

We measured macroscopic properties (water permeability, mechanical strength) of the cured paste. As already mentioned earlier, the main aim of the cementing operation is to avoid fluid circulation between different geological layers. In absence of large cracks in cement sheath and/or plug or micro-annuli at the interfaces cement/rock or cement/casing, the transport of fluids within the cementitious matrix is mainly a diffusive process. To characterize the evolution of the transport properties of the matrix, the diffusion coefficient of ionic species should be measured instead of the permeability. Nonetheless, permeability of cement-based material is assumed to be a relevant index to assess its durability. Water permeability has been measured by using an Hassler cell. The experiment consists in applying a differential pressure between the extremities of a cylindrical sample in order to develop a water flow, and in recording the corresponding flow rate. The flow rate is determined by continuously weighing the water at the outlet of the setup. To force the water through the cementitious matrix and to avoid water leakage, the set cementitious sample is placed in a deformable sleeve which is pressurized to ensure water tightness (we note $P_{c}$, this confining pressure). The upward pressure, $P_{1}$, is fixed at the confining pressure minus $3 \mathrm{MPa}$. The downward pressure, $P_{2}$, is equal to atmospheric pressure. Darcy's law for a non-compressible fluid is used to calculate the water permeability $k_{w}$ :

$$
Q=k_{w} \frac{S}{\eta} \frac{P_{1}-P_{2}}{l}
$$

where $\eta(\mathrm{Pa} \cdot \mathrm{s})$ is the water viscosity, $l(\mathrm{~m})$ and $S\left(\mathrm{~m}^{2}\right)$ are respectively the length and the cross-sectional area of the cylinder and $Q$ the flow rate $\left(\mathrm{m}^{3} \cdot \mathrm{s}^{-1}\right)$.

As stated by different authors [27-29], this technique presents some drawbacks. During the measurement, leaching or/and hydration can modify the porous texture of the matrix and finally influence permeability value. The water saturation of the studied samples is an important factor as well. The mechanical loading applied to the cylinder is essential [30]. In a same way, confining pressure, $P_{c}$, can cause variations of permeability. To take into account this effect of the confining pressure on the permeability measurement, we carried out the experiments at two different confining pressures, 4 and 8 $\mathrm{MPa}$. The given water permeability is an average of the values obtained for the two different operating conditions.

The mean water permeability of the set cement paste is $6 \cdot 10^{-19} \mathrm{~m}^{2}$.

We performed flexural strength measurements from 3-point bending test and Young's modulus and compressive strength measurements. The compression tests have been performed on cubes $(2 \times 2 \times 2 \mathrm{~cm})$ and on cylindrical samples (diameter: $2.5 \mathrm{~cm}$, height: $5 \mathrm{~cm}$ ). We only present in this paper the compressive strength values. The evolution of the flexural strength and Young's modulus will be presented elsewhere.

\subsection{Ageing Tests under Static Conditions with no Replacement of Water}

After the curing, specimens are placed in an autoclave filled with water. The water volume to samples volume 
ratio is comprised between 3 and 5. Figure 6 shows the variation versus time of the compressive strength for samples aged in water without renewal of the water for one year. During the first six months, the mechanical strength does not vary significantly. But after one year, the compressive strength is starting to slowly decrease. After one year of ageing, the loss of mechanical integrity of hardened cement paste is $\sim 20 \%$. In this case, the impairment of mechanical strength is related to porous texture and C-S-H evolution of the cement paste. Indeed, denser C-S-H are generally observed when the curing temperature of the cement pastes is increased [31]. For temperature above $\sim 120^{\circ} \mathrm{C}$, it is well known that a neat cement paste (without silica source) show strength retrogression due the formation of $\alpha$-dicalcium silicate hydrate $\left(\alpha-\mathrm{C}_{2} \mathrm{SH}\right)$ at the expense of amorphous C-S-H [31-34]. For lower temperatures, results show a deterioration of mechanical properties associated with an increasing water permeability [35]. The observed decrease of strength is linked to both a higher porosity and a coarser pore size distribution. For pastes hydrated at moderate temperature (typically $\sim 50-80^{\circ} \mathrm{C}$ ), the calcium silicate hydrates are denser than the ones formed when the hydration takes place at $20^{\circ} \mathrm{C}[31,36]$. As reported in [35], the impairment of mechanical strength is a phenomenon dependent on temperature. The higher the temperature, the earlier and the more important the loss of mechanical integrity.

In our experimental conditions, the variations of the macroscopic properties are due to a temperature effect and not to the chemical attack. To definitely conclude and highlight the temperature effect on the mechanical properties impairment, ageing of the same paste in an aqueous solution mimicking pore solution would be necessary.

\subsection{Ageing Tests under Static Conditions with Periodic Replacement of Water}

It is clear from the previous section that in case of no renewal of the ageing fluid, the variations of the properties of hardened cement paste aged at moderate temperature are very limited during the first year. These variations are induced by temperature-driven chemical transformations.

Figure 7 illustrates the time evolution of the compressive strength of the same cement paste with water replacement. During the first four months, the compressive strength exhibits the same variation than observed with no renewal of the ageing fluid. After 4 months, the compressive strength starts to decrease importantly. After one year, the variation of the compressive strength falls of $50 \%$.

For mechanical properties, the renewal of the ageing fluid has two main effects:

- firstly, the mechanical resistance is impacted earlier,

- secondly, about half of the mechanical strength is lost after one year.

The question is how to explain the lower compressive strength measured for samples aged with ageing fluid replacement. First of all, we verified that the degree of hydration was identical between the two set of experiments. We calculated the degree of hydration thanks to solid-state ${ }^{29} \mathrm{Si}$ NMR experiments [37]. In the case of "No renewal", the degree of hydration was $90 \%$. And in the case of "Periodic

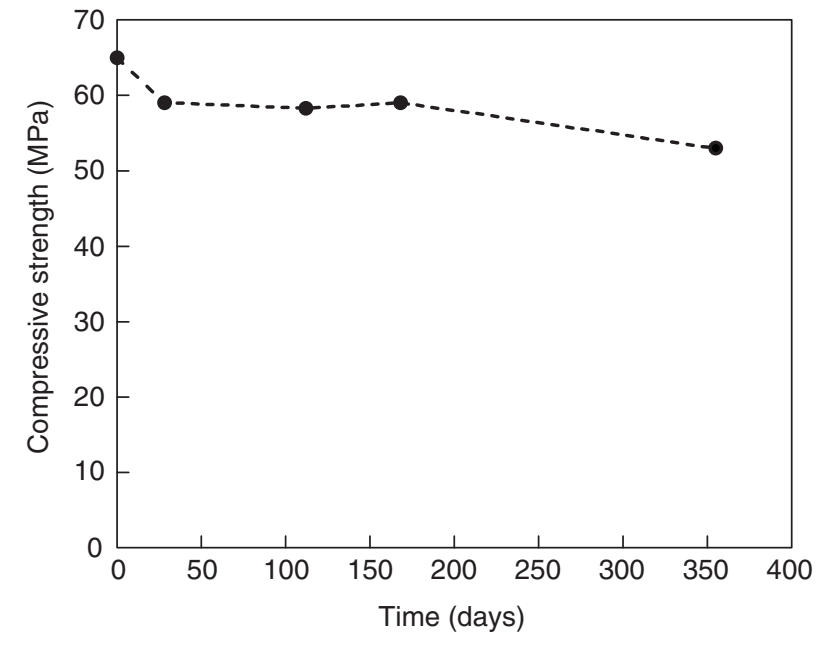

Figure 6

Uniaxial compressive strength of hardened cement paste aged in water at $80^{\circ} \mathrm{C}$ with no replacement of the water.

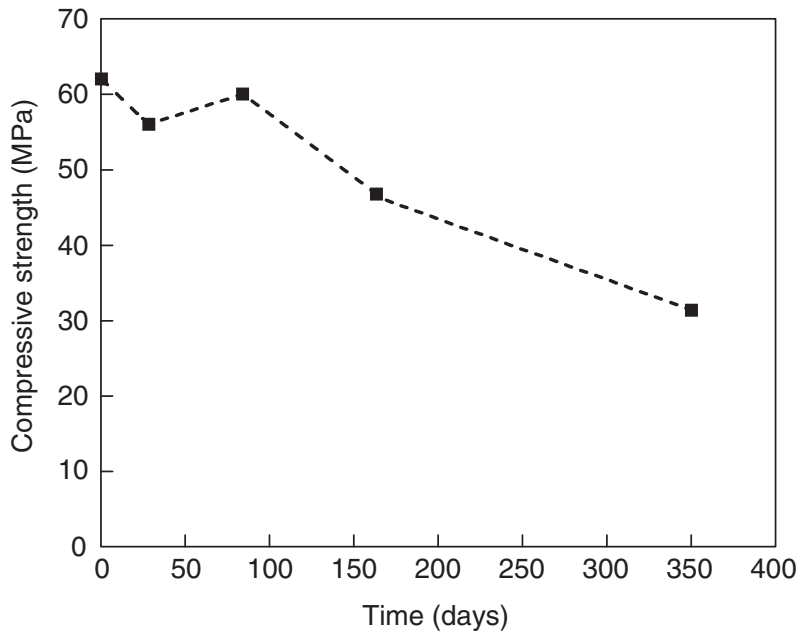

Figure 7

Uniaxial compressive strength of hardened cement paste aged in brine at $80^{\circ} \mathrm{C}$ with monthly replacement of the water 
renewal", the degree of hydration was $85 \%$. The difference of evolution for compressive strength could be due to specific chemical transformations of the binding phases and/or to crystallization of new phases. So, we investigated the chemical evolution of the material along the ageing time.

Le Saoût et al. [37] reported the chemical evolution of the hardened cement paste aged in the same conditions. After one year, they observed that both the degree of hydration and the degree of C-S-H connectivity increases. Concerning the C-S-H, little change of structure as probed by ${ }^{29} \mathrm{Si}$ NMR has been shown. The main difference after one year is the disappearance of the portlandite in the outer part of the samples. The disappearance of the portlandite occurs in the outer layer of $\sim 200-300 \mu \mathrm{m}$ in thickness. The thickness of the leached zone is lower than the one measured by Kamali [38]. For a cement paste with a water/cement ratio of 0.4 leached at $85^{\circ} \mathrm{C}$ for 4 months, the leached zone was $\sim 1.3 \mathrm{~mm}$ thick. The estimation, from the results of Kamali, of the degraded layer thickness corresponding to 1 year of leaching gives a value ten times higher than that we observed. But we have to keep in mind that Kamali performed her leaching experiments with running water (the flow rate was $1 \mathrm{~L}$ per day), and, she used a very low salinity water (the ionic strength was less than 4 $\left.\mathrm{mmol} \cdot \mathrm{L}^{-1}\right)$. In her thesis, Kamali showed that the thickness of the degraded layer decreases when the salinity of the water increases. The results published in the present paper corroborate the conclusions drawn in [38].

XRD experiments reveal the same mineralogy as the one observed in hardened cement paste aged in static conditions with no water renewal. Therefore, we would explain the lower compressive strength of the samples aged with fluid

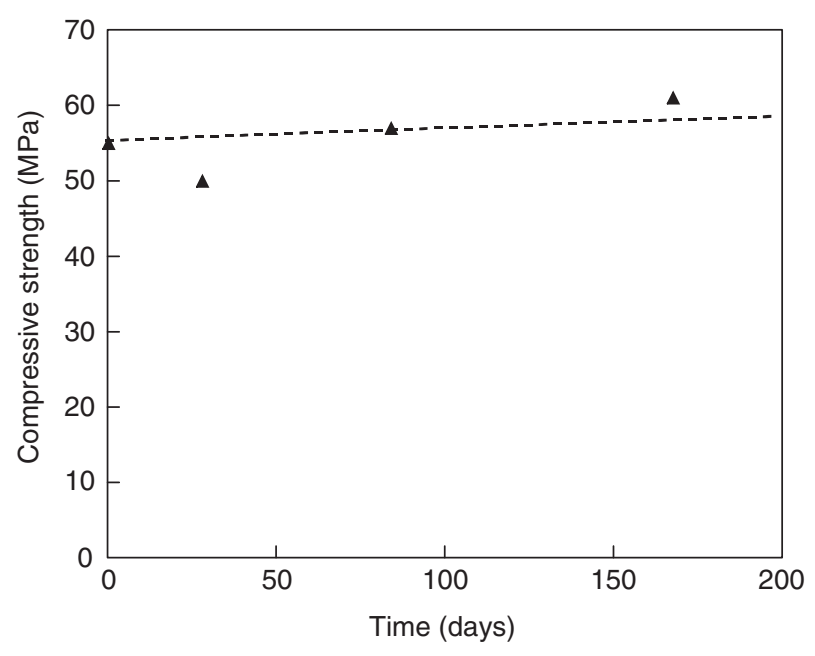

Figure 8

Uniaxial compressive strength of hardened cement paste aged in crude oil at $80^{\circ} \mathrm{C}$ with no replacement. renewal by the leaching of the portlandite [38, 39]. However, it is important to recall that fluid renewal requires monthly depressurization/pressurization cycle and cooling. This procedure could have an effect on the material by inducing micro-crackings. A better way to carry out such experiment would be to renew the ageing fluid under pressure and temperature. This type of experiment is currently under way in our laboratory [40].

\subsection{Ageing Tests under Static Conditions with no Replacement of Crude Oil}

Figure 8 displays the evolution with time of the compressive strength of samples aged in crude oil. Contrary to what we observed in the two previous experiments, the compressive strength remains stable over time. Nonetheless, it would be necessary to continue the experiment over a longer duration. But our result is in agreement with those published by Živica [41] who investigated the long-term effects of crude oil on different mortars. To confirm the non alteration of the cement paste, we measured the portlandite content by TGA. After 6 months in crude oil, the $\mathrm{CH}$ amount in cement paste was $16 \%$ which is about the same value measured before the ageing (17\%). Another way to highlight cementitious matrix degradation is to use electron microprobe. We investigated the chemical composition of the cement paste immerged 6 months in crude oil. The microprobe profiles have been measured from the edge of the sample to the core (over a length of $14 \mathrm{~mm}$ ). As one can see in Figure 9, we do not observe any calcium depletion in the paste (the abscissa 0 corresponds to the outer side of the sample in contact with the oil). From a chemical point of view, there is no degradation of the cement matrix.

Variations of water permeability and mercury porosity are shown in Figure 10. The permeability of the sample decreases during the first month and then reaches a plateau around $4-5 \cdot 10^{-19} \mathrm{~m}^{2}$. The porosity exhibits the same trend. The measurement of water permeability for these samples is questionable. Indeed, after six months, the crude has deeply penetrated within the matrix. Even if we flushed the samples with water to remove hydrocarbons out the pores of the cementititous paste, it is likely that during the permeability measurement oil is still present within the paste. The presence of hydrocarbons modifies the water flow inside the porous space and consequently the permeability values.

Over the duration of the experiment, the crude oil used for this study which does not contain acidic compounds seems to be harmless for the hardened portland cement paste. Nonetheless, the study has to be repeated with two major modifications before drawing definite conclusions about the durability of cement-based materials in reservoir conditions:

- to use an ageing fluid representative of reservoir fluids which is a mixture of gas, hydrocarbons and brines, 


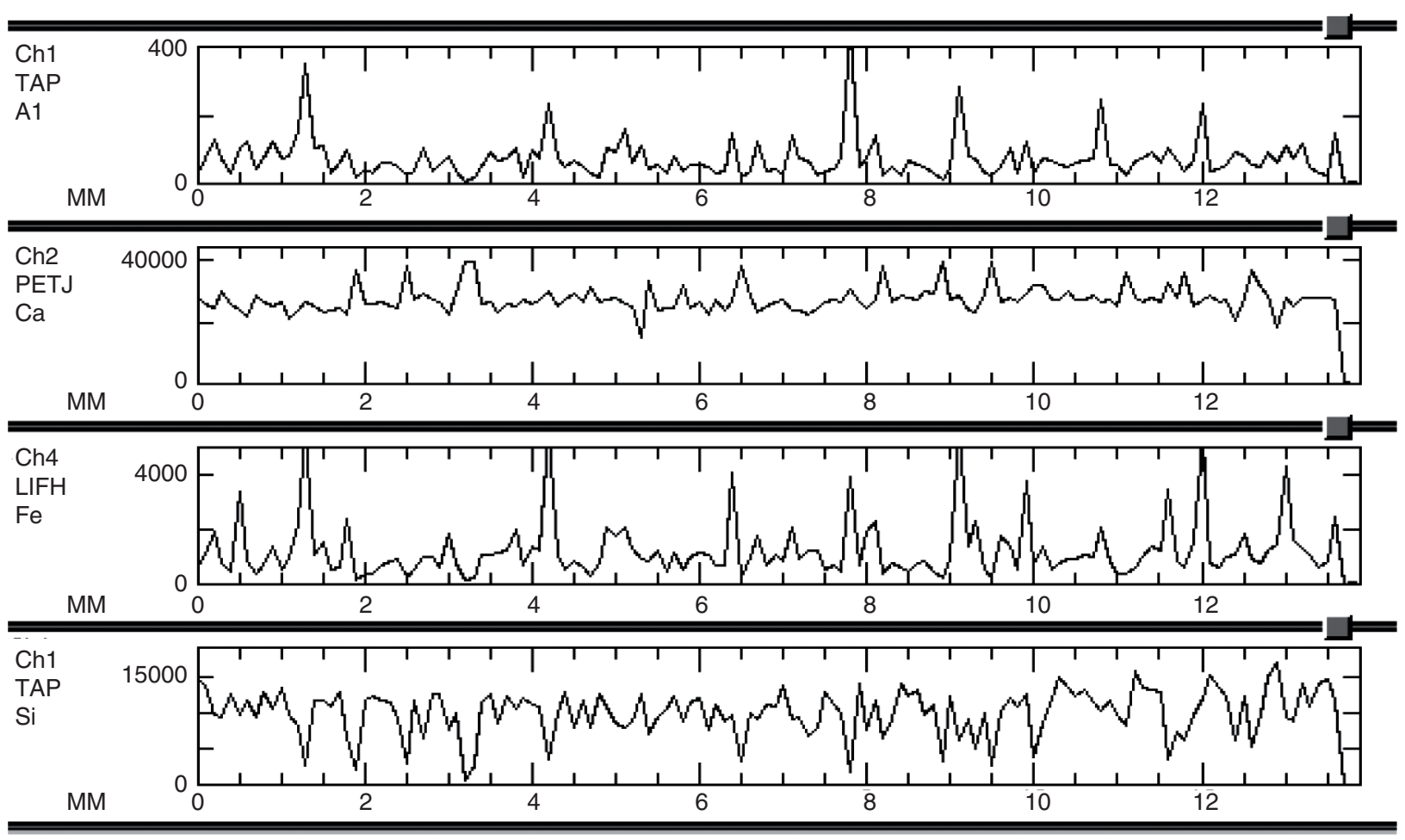

Figure 9

Microprobe profiles obtained by electron microprobe on the hardened cement paste aged for 6 months in crude oil.

- to replace periodically the ageing fluid.

Such a research program is currently finishing in our laboratory. Some results of experiments taking into account the first point have already been published by Noik and Rivereau [35].

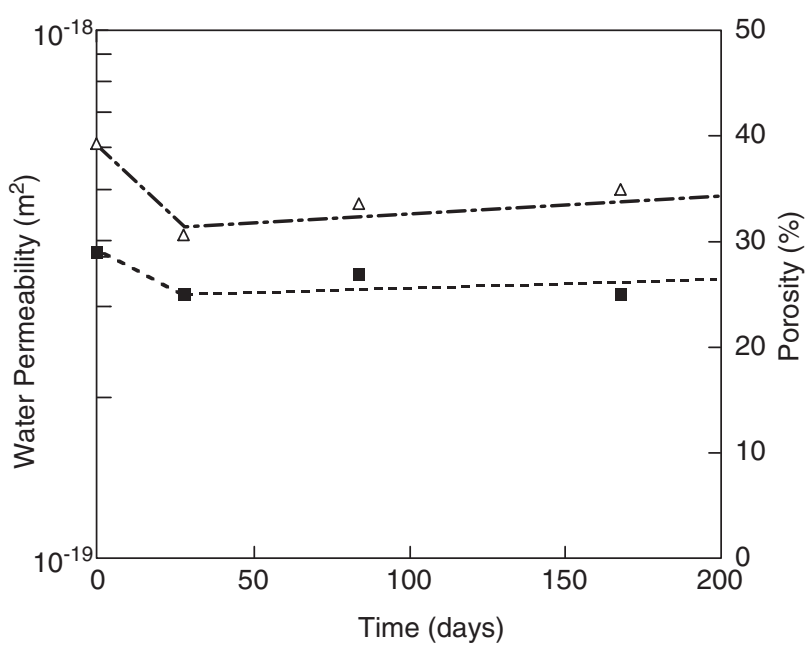

Figure 10

Variation of water permeability (triangle, left axis) and porosity (square, right axis) of cement paste immerged for 6 months in crude oil.

\section{SUMMARY AND CONCLUSIONS}

The purpose of this paper was to assess the long term integrity of hardened cement used for oilwell cementing. Ageing tests have been carried out up to one year. Various experimental conditions were applied to evaluate at the same time the cementitious materials integrity and the best ageing protocol of cementing materials.

For cementitious paste aged in water in static conditions for one year, we observed mechanical properties impairment of $\sim 20 \%$. Even if temperature and pressure are high, no dissolution and/or precipitation phenomena occur leading to the degradation of macroscopic properties of cement matrix.

The hardened cement paste aged in monthly renewed low salinity water exhibits a significant decrease $(\sim 50 \%)$ of mechanical strength. This degradation could be related to the leaching of portlandite, even if this disappearance does not occur in all the sample volume. Another explanation could be the appearance of micro-cracks due to depressurization and cooling of the cell necessary for the replacement of the ageing fluid.

For cementitious paste aged in crude oil, we did not observe any mechanical properties impairment in comparison with what we observed on the same material aged in water. This can be explained by the absence of acidic compounds in the crude. 
Consequently, the conclusions of the ageing tests can vary with the boundary conditions (fluid volume/materials volume ratio, frequency of renewal...). For example, a fluid volume/materials volume ratio of $\sim 5$ without any fluid replacement is not sufficient to observe chemical attack of the samples. The results reported in this paper illustrate the difficulty to assess durability of cement-based materials in downhole conditions.

To forecast the durability of cementing materials, durability tests have to mimic the in situ leaching processes of the cement-based materials. For instance, in absence of large cracks in cement sheath and/or plug or micro-annuli at the interfaces cement/rock or cement/casing, the leaching of the cementitious matrix is a purely diffusive mechanism. Besides, the aggressive chemicals enter in contact with the cement paste throughout the surrounding rocks. So, one can expect a slow kinetics of the matrix degradation comparatively with laboratory results.

What should be the protocol to be used to characterize the kinetics of degradation? We overestimate the alteration front rate with running water test. Nonetheless, we get information (mechanical properties, transport properties: certainly the most important data) on the ultimate degraded materials. In this case, the former question becomes: when will this ultimate degraded material appear: 50 years, 500 years, 5000 years? To evaluate over thousands of years the integrity of cementing materials used to plug oilwells, the use of coupled chemical-transport code allowing to predict both chemical (precipitation and dissolution of minerals) and physical (pore structure, transport properties) evolutions of the materials seems impossible to circumvent.

As one can see, the work to be done in the next years is huge before being able to forecast cementing and plugging material durability. It could be valuable and fruitful for our industry to set up a working group in charge of establishing guidelines to carry out durability tests. These guidelines would allow to save time by carrying out reliable time consuming experiments and to get meaningful results.

\section{REFERENCES}

1 Jacquemet, N., Pironon, J. and Caroli, E. (2005) A new experimental procedure for simulation of $\mathrm{H}_{2} \mathrm{~S}$ and $\mathrm{CO}_{2}$ geological storage: application to well cement ageing. Oil Gas Sci. Technol., 60, 193-203.

2 Barlet-Gouédard, V., Rimmelé, G., Goffé, B. and Porcherie, O. (2006) Mitigation strategies for the risk of $\mathrm{CO}_{2}$ migration through wellbores. IADC/SPE 98924, IADC/SPE Drilling Conference, Miami, Florida, USA, 21-23 February. BarletGouédard, V., Rimmelé, G., Goffé, B. and Porcherie, O. (2007) Well technologies for $\mathrm{CO}_{2}$ geological storage: $\mathrm{CO}_{2}$-resistant cement. Oil Gas Sci. Technol., 62, 325-334.

3 Onan, D.D. (1984) Effects of supercritical carbon dioxide on well cements. SPE 12593, Permian Bassin Oil \& Gas Recovery Conference, Midland, Texas, USA, March 8-9. Bruckdorfer, R.A. (1986) Carbon dioxide corrosion in oilwell cement. $S P E$
15176, Rocky Mountain Regional Meeting, Billings, Montana, USA, May 19-21. Shen, J.C. and Pye, D.S. (1989) Effects of $\mathrm{CO}_{2}$ attack on cement in high-temperature applications. SPE/IADC 18618, SPE/IADC Drilling Conference, New Orleans, Louisiana, USA, February 28-March 3.

4 Groves, G.W., Brough, A., Richardson, I.G. and Dobson, C.M. (1991) Progressive changes in the structure of hardened $\mathrm{C}_{3} \mathrm{~S}$ cement pastes due to carbonation. J. Am. Ceram. Soc., 74, 28912896. Thiery, M. (2005) Modélisation de la carbonatation atmosphérique des matériaux cimentaires - Prise en compte des effets cinétiques et des modifications microstructurales et hydriques. Thesis, École Nationale des Ponts et Chaussées (in french).

5 Van Gerven, T., Van Baelen, D., Dutré, V. and Vandecasteele, C. (2004) Influence of carbonation and carbonation methods on leaching of metals from mortars. Cement Concrete Res., 34, 149156.

6 Krilov, Z., Loncaric, B. and Miksa, Z., (2000) Investigation of a long-term cement deterioration under a high-temperature, sour gas downhole environment. SPE 58771, International Symposium on Formation Damage Control, Lafayette, Louisiania, USA, 23-24 February.

7 Lécolier, E., Rivereau, A., Ferrer, N., Audibert, A. and Longaygue, X. (2006) Durability of oilwell cement formulations aged in $\mathrm{H}_{2} \mathrm{~S}$-containing fluids. IADC/SPE 99105, IADC/SPE Drilling Conference, Miami, Florida, USA, 21-23 February.

8 Nelson, E.B. (Ed.) (1990) Well Cementing, Schlumberger Educational Services, Houston.

9 Taylor, H.F.W. (1997) Cement Chemistry, 2nd Edn., Thomas Telford Publishing, London.

10 Powers, T.C. (1958) Structure and Physical Properties of Hardened Portland Cement Paste. J. Am. Ceram. Soc., 41, 1-6 and references therein.

11 Nachbaur, L., Mutin, J.C., Nonat, A. and Choplin, L. (2001) Dynamic mode rheology of cement and tricalcium silicate pastes from mixing to setting. Cement Concrete Res., 31, 183-192.

12 Jiang, S.P., Mutin, J.C. and Nonat, A. (1995) Studies on the Mechanism and Physico-Chemical Parameters at the Origin of Cement Setting. I. The Fundamental Processes involved during Cement Setting. Cement Concrete Res., 25, 779-789.

13 Jiang, S.P., Mutin, J.C. and Nonat, A. (1996) Studies on the Mechanism and Physico-Chemical Parameters at the Origin of Cement Setting. II. Physico-Chemical Parameters determining the Coagulation Process. Cement Concrete Res., 26, 491-500.

14 Nachbaur, L., Nkinamubanzi, P.C., Nonat, A. and Mutin, J.C. (1998) Electrokinetic Properties which control the Coagulation of Silicate Cement Suspensions during Early Age Hydration. $J$. Colloid Interf. Sci., 202, 261-268.

15 Garrault-Gauffinet, S. and Nonat, A. (1999) Experimental Investigation of Calcium Silicate Hydrate (C-S-H) Nucleation. $J$. Cryst. Growth, 200, 565-574.

16 Maggion, R., Bonnamy, S., Levitz, P. and Van Damme, H. (1996) A scaling model of the microstructural evolution in $\mathrm{C}_{3} \mathrm{~S} / \mathrm{C}-\mathrm{S}-\mathrm{H}$ pastes. In: The Modeling of Microstructure and its Potential for Studying Transport Properties and Durability, Jennings, H., Kropp, J. and Scrivener, K. (Eds.) NATO ASI Series E : Applied Sciences, 304, Kluwer Academic Publishers, Dordrecht, 137-155.

17 Levitz, P. (2006) Toolbox for 3D imaging and modeling of porous media: Relationship with transport properties. Cement Concrete Res., in press.

18 Maggion, R., Tinet, D., Levitz, P. and Van Damme H. (1992) Microtextural evolution of CSH pastes during hydration. In: Hydration and Settings of Cement, Edited by A. Nonat and J.C. Mutin. RILEM Proceedings 16, E\&FN SPON. 
19 Lea (1998) Chemistry of cement and concrete, Fourth Edition, Editet by Peter C. Hewlett.

20 Diamond, S. (2000) Mercury porosimetry: An inappropriate method for the measurement of pore size distributions in cementbased materials. Cement Concrete Res., 30, 1517-1525.

21 Olson, R.A., Neubauer, C.M. and Jennings, H.M. (1997) Damage to the pore structure of hardened porltand cement paste by mercury intrusion. J. Am. Ceram. Soc., 80, 2454-2458.

22 Halperin, W.P., Jehng, J.-Y. and Song, Y.-G. (1994) Application of spin-spin relaxation to measurement of surface area and pore size distributions in a hydrating cement paste. Magn. Reson. Imaging, 12, 169-173.

23 Korb, J.-P., Petit, D., Philippot, S., Zanni, H., Maret, V. and Cheyrezy M. (1998) Nuclear relaxation of water confined in reactive powder concrete. In: Zanni H., Soozzani P. (Eds.). Nuclear Magnetics Resonance Spectroscopy of Cement-Based Materials. Springer, Berlin.

24 Plassais, A., Pomiès, M.-P., Lequeux, N., Boch, P., Korb, J.-P., Petit, D. and Barberon, F. (2003) Micropore size analysis by NMR in hydrated cement. Magn. Reson. Imaging, 21, 369-371.

25 Le Saoût, G., Lécolier, E., Rivereau, A. and Zanni, H. (2005) Micropore size analysis in oil-well cement by proton nuclear relaxation. Magn. Reson. Imaging, 23, 371-373.

26 Le Saoût, G., Lécolier, E., Rivereau, A. and Zanni, H. (2004) Study of oilwell cements by solid-state NMR. C. R. Chimie, 7, 383-388.

27 Powers, T.C., Copeland, L.E. and Mann, M. (1959) Capillary continuity or discontinuity in cement pastes. J. Portland Cem. Assoc. Res. Dev. Lab., May issue, 38-48.

28 Nyame, B.K. and Illston, J.M. (1988) Capillary pore structure and permeability of hardened cement pastes. Proc. 7th Int. Conf. Cement Chem., vol. III, Editions Septima, Paris, VII-181-VII185.

29 Hooton, R.D. (1989) What is needed in a permeability test for evaluation of concrete quality? In: Roberts, L.R. and Skalny, J.P. (Eds.), Pore structure and permeability of cementitious materials, Vol. 137, Materials Research Society, 141-149.

30 Banthia, N., Biparva, A. and Mindess, S. (2005) Permeability of concrete under stress. Cement Concrete Res., 35, 1651-1655.

31 Masse, S. (1993) Synthèse hydrothermale d'hydrates de silicate tricalcique : Analyse structurale en phase solide - Etude compar- ative avec les ciments utilisés pour chemiser les puits de pétrole. PhD Thesis, Université Pierre et Marie Curie.

32 Eilers, L.H. and Root, R.L. (1974) Long-term effects of high temperature on strength retrogression of cements. 49th Annual Fall Meeting of the SPE of AIME, SPE 5028, Houston, Texas, USA, October 6-9.

33 Grabowski, E. and Gillot, J.E. (1989) The effect of initial curing temperature on the performance of oilwell cements made with different types of silica. Cement Concrete Res., 19, 703-714.

34 Méducin, F. (2001) Etude des phases silicatées du ciment hydraté sous haute pression et haute température. PhD Thesis, Université Pierre et Marie Curie.

35 Noik, C. and Rivereau, A. (1999) Oilwell cement durability. SPE 56538, Annual Technical Conference and Exhibition, Houston, Texas, USA, 3-6 October. Noïk, C., Rivereau, A. and Vernet, C. (1998) Novel cements materials for high-pressure/high-temperature wells. SPE 50589, SPE European Petroleum Conference, The Hague, The Netherlands, 20-22 October.

36 Kjellsen, K.O., Detwiler, R.J. and Gjørv, O.E. (1990) Backscattered electron imaging of cement pastes hydrated at different temperatures. Cement Concrete Res., 20, 308-311. Kjellsen, K.O., Detwiler, R.J. and Gjørv, O.E. (1990) Pore structure of plain cement pastes hydrated at different temperatures. Cement Concrete Res., 20, 927-933.

37 Le Saoût, G., Lécolier, E., Rivereau, A. and Zanni, H. (2006) Chemical structure of cement aged at normal and elevated temperatures and pressures - Part I. Class G oilwell cement. Cement Concrete Res., 36, 71-78.

38 Kamali, S. (2003) Comportement et simulation des matériaux cimentaires en environnements agressifs : lixiviation et température. PhD Thesis, École Normale Supérieure de Cachan (France).

39 Carde, C. (1996) Caractérisation et modélisation de l'altération des propriétés mécaniques due à la lixiviation des matériaux cimentaires. PhD Thesis, INSA de Toulouse (France).

40 Neuville, N. (in preparation) Caractérisation et modélisation de l'altération physico-chimique des ciments utilisés dans les puits pétroliers. PhD Thesis, École des Mines de Paris (France).

41 Živica, V. (1995) The quality of cement composites after longterm contact with hydrocarbon media. Arab. J. Sci. Eng., 20, 467-479.

Final manuscript received in April 2007 